\title{
IRONICZNA BEZDOMNOŚĆ BOHUMILA HRABALA A TEUMIONA TĘSKNOTA ZA DOMEM MILANA KUNDERY
}

\author{
JAKUB ČEŠKA ${ }^{1}$
}

(Praha)

\begin{abstract}
Słowa kluczowe: Bohumil Hrabal, Milan Kundera, naratologia
\end{abstract}
Keywords: Bohumil Hrabal, Milan Kundera, narratology

\begin{abstract}
Abstrakt: Jakub Češka, IRONICZNA BEZDOMNOŚĆ BOHUMILA HRABALA A TŁUMIONA TĘSKNOTA ZA DOMEM MILANA KUNDERY. „PORÓWNANIA” 11, 2012, Vol. XI, ss. 87-99, ISSN 1733-165X. Posługując się tematyką sentymentu odsłaniamy kontrast między pisarstwem Milana Kundery i Bohumila Hrabala, przy czym odwracamy powszechnie przyjęte charakterystyki. Chociaż Kunderze przyczepia się etykietkę autora cynicznego, nieromantycznego, antysentymentalnego, Hrabal zaś bywa klasyfikowany jako autor wrażliwego zrozumienia, to jednak przez tematykę domu można pokazać, że jest właściwie odwrotnie. Argumenty znajdujemy na poziomie écriture: Pisanie Kundery odznacza się dystynktywnością, znaczeniowym dookreśleniem i specyficzną wewnętrzną fokalizacją. Tymi rysami wpisuje się $\mathrm{w}$ tematykę potępienia, renegacji, polaryzacji alternatywy dom - obczyzna. Każdy z autorów proponuje inną odpowiedź na pytanie o tęsknotę za domem: Hrabal stosuje figurę cynicznie akceptowanej bezdomności, podczas gdy u Kundery znajdujemy tłumiony sentyment, z którego wywiera tęsknota za domem.
\end{abstract}

Abstract: Jakub Češka, HOMELESSNESS IRONICALLY ACCEPTED BY HRABAL VERSUS KUNDERA'S SUPPRESSED HOMESICKNESS. "PORÓWNANIA" 11, 2012, Vol. XI, pp. 87-99, ISSN 1733-165X. By means of using the topic of sentiment, the contrast between the writing of Milan Kundera and Bohumil Hrabal is shown. All the typically acknowledged characteristics are reversed. Although Kundera is assigned a label of a cynical, unromantic and antisentimental author and Hrabal is often classified as an author of sensitive understanding, it is through the topic of the home that the reversed can be shown. The arguments can be found on the level of écriture: Kundera's writing is distinctive, semantically detailed and possesses internal focalisa-

\footnotetext{
${ }^{1}$ Correspondence Address: ceska@fhs.cuni.cz
} 
tion. These characteristics allow him to enter the topic of condemnation, renegation and the polarisation of the alternative between the home and the foreign. Each of the authors proposes a different answer to the question on homelessness: Hrabal uses the figure of cynically accepted homelessness whereas Kundera a suppressed sentiment which emanates with homelessness.

Swoiste cechy pisarstwa Milana Kundery i Bohumila Hrabala można przeciwstawiać na kilka różnych sposobów. Możemy mówić o ideologicznym écriture (pisaniu) Kundery (w bardzo specyficznym sensie, ponieważ chodzi o demaskowanie ideologii) w opozycji do Hrabalowskiego nieideologicznego; nie można też zapominać o radykalnie różnej strategii narracyjnej obu autorów. Antyiluzyjnej, wywłaszczającej taktyce ledwie nanoszonych znaczeń u Kundery przeciwstawia się prostolinijna iluzyjność pisania Hrabala, co możemy ukazać przez odrębność form narracyjnych. Wypracowana konstrukcja Kunderowskiej narracji, gra z narratorem, autorskie wtręty, sytuują się w opozycji do wstrzemięźliwie opowiadanej prozy Bohumila Hrabala. Możemy też dostrzec u Hrabala liczne znamiona realizmu (cóż z tego, że wybierane strategicznie), u Kundery zaś przykłady forsowania literackości powieściowego świata, który z tym naszym nie ma nic wspólnego, mimo iż czasem nań spoglądamy, nie zauważając, że mamy do czynienia, co najmniej z krzywym zwierciadłem.

\section{HRABALOWSKIE NIEZLOKALIZOWANE ANEGDOTY WOBEC MOCNO OSADZONYCH MOTYWÓW KUNDERY}

W uogólnionym ujęciu możemy mówić o skupionym - dośrodkowym czy koncentrycznym pisaniu Milana Kundery, w odróżnieniu od rozproszonego écriture Bohumila Hrabala. Wynika to zapewne z autorefleksyjności pisarstwa Kundery, której Hrabal, być może strategicznie, unika. Co za tym idzie, u Kundery w jego surowym narratorskim dookreśleniu i w jego nagości możemy odkryć bezpośredniość (pospiesznie i nietrafnie moglibyśmy ją określić jako dydaktyzm), tymczasem małomówny (melancholijny) sposób pisania Hrabala będziemy odbierać jako nieoczywisty, ironiczny i wywłaszczający. W ten sposób strategicznie czytelny gest u Kundery możemy skontrastować z nieczytelnymi w rzeczy samej grymasami Hrabala.

Nie trzeba raczej przypominać, że w obu przypadkach chodzi o pisanie skomponowane literacko (określmy je jako zrymowane) i to w odmienny sposób. Nie wdając się w szczegóły, możemy jednak w prostym fakcie przypominania sobie określonej tematyki (w tym wypadku tematyki domu) odnotować trudność ewokacji prozy Hrabala i odwrotnie łatwość namysłu nad powieściami Kundery. Zapewne można to złożyć na karb uporządkowania i czytelności (w sensie znaczeniowej stabilności i spójności) prozy Kundery (o czym wspomnieliśmy już wyżej), 
wobec nieuporządkowania $\mathrm{w}$ pisarstwie Hrabala, zrymowanym anegdotycznie i pewnie z tego powodu nie mającym czytelnej składni, którą moglibyśmy w "logice" écriture lepiej zapamiętać. Jak gdyby obiekty, które Kundera w specyficzny sposób literacko konstruuje, zyskały określony zasięg i głębię - może dlatego domagają się własnego kontekstu. U Hrabala odwrotnie - właściwe mu anegdotyczne rozproszenie powoduje, że motywy jakby traciły swoje miejsca, nie jest bowiem oczywiste, dlaczego występują właśnie w tym, a nie w innym miejscu. Drobne motywy w dziele Hrabala powtarzają się wszak w różnych kontekstach², w których bywają $\mathrm{w}$ rozmaity sposób semantyzowane. Toteż nowele Hrabala sprawiają wrażenie, jakby je było można porozcinać i znów złożyć, a to z pewną dozą paradoksu, często bowiem są rozumiane realistycznie: atomem Hrabalowskiej narracji jest właśnie anegdota.

W przeciwieństwie do tego motywy Kundery są wskaźnikami pewnego specyficznego kontekstu. Możemy mówić o składni motywów, przy czym dziwność będzie podstawowym kontekstem motywu. Niemałą korzyścią czytelności będzie ponadto jej komplementarność, nie wykazuje ona przecież żadnego nadmiaru, do którego mogłaby się wśliznąć nieskrępowana (fluktuująca) anegdota. U Hrabala odwrotnie - rozluźniona składnia narracji umożliwia ofensywę błądzącej anegdoty, na przykład nieoczekiwany kontekst domu w opowiadaniu Beatrycze (w zbiorze Święto przebiśniegu): tęsknota za domem jest tu związana z demencją i szaleństwem.

Ów odmienny charakter écriture Milana Kundery i Bohumila Hrabala ma swoje odbicie również $\mathrm{w}$ odrębnej pragmatyce interpretacji: do rozpatrzenia tematyki domu u Kundery interpretatorowi wystarczy własna pamięć (wyrazista składnia motywów będzie jej sprzyjać), tymczasem, by dosięgnąć przynajmniej znaczeniowego horyzontu omawianej tematyki u Hrabala, będziemy się posiłkować opracowaniem korpusu jego tekstów ${ }^{3}$. Praktyka i doświadczenie pracy z korpusem potwierdzi to, co zostało powiedziane o fluktuacji anegdot. Gdy tematyka domu ujawnia się w błądzącej (dygresyjnej) anegdocie, to oczywiście niemal nie możemy sobie jej przypomnieć (zastanawiając się, będziemy ją, co najwyżej, z trudem lokalizować), ale co więcej, możemy powiedzieć, że anegdotę, jako poboczny motyw, uczyniono niewidoczną, została przesłonięta przez zasadniczą kanwę noweli.

Pytanie, czy - odwrotnie - nowele Hrabala nie mają w rzeczywistości bardziej złożonej, narracyjnej składni, pozostawmy bez odpowiedzi. Komplikowałaby ją wstrzemięźliwość Hrabalowskiego narratora. Czyż poszukiwania złożoności składni narracyjnej Hrabala nie sprowadzałyby się niemal wyłącznie do egzegetycznego wysiłku interpretatora, z jedynie prawdopodobnym świadectwem tekstu?

2 O wariantywności w prozie Hrabala por.: S. Roth, Hlučná samota a hořké štěstí Bohumila Hrabala. Praha 1993; J. Češka, Psaní Bohumila Hrabala na pomezí literatury. „Slovo a smysl. Časopis pro mezioborová bohemistická studia“ 2010, nr 7, s. 53-73.

${ }^{3}$ Slovník Bohumila Hrabala. Red. F. Čermák, V. Cvrček. Praha 2009. 
Pozostawmy owe kłopotliwe kwestie na boku, wystarczy nam stwierdzenie, że motyw domu u Hrabala nie jest punktem zbiegu motywów (jak u Milana Kundery), co jednak nie powinno nam przeszkodzić w próbie naszkicowania jego wizerunku. Czyż tematyka domu u Hrabala nie okaże się w sposób wieloznaczny peryferyjna, ale jednocześnie centralna, gdy u Milana Kundery motyw ten odgrywa podstawową rolę? Już choćby na przykładzie Hrabalowskiej wieloznaczności (dom jako centrum peryferii) kontrastującej ze znaczeniową stabilnością Kundery możemy zaobserwować $\mathrm{z}$ jednej strony kolejne cechy odróżniające ich sposoby pisania, z drugiej zaś odnotować ślad horyzontu interpretacji, w którym chcemy tę tematykę rozpatrywać. Wstępna teza mogłaby brzmieć następująco: odmienne pojmowanie tematyki domu wynika z odmiennego literacko charakteru écriture.

$\mathrm{Z}$ tego, co zostało dotąd powiedziane, jest już jasne, które swoiste cechy pisania będą bardziej kłopotliwe dla interpretacji. Żeby oprzeć analizę na trwalszych podstawach, korzystnie będzie rozpocząć od wyjaśnienia tematyki domu u Milana Kundery. Najpierw weźmiemy pod uwagę strategię narracyjną Kundery, którego pisanie wpisuje się $\mathrm{w}$ istotę tematyki domu, następnie zajmiemy się dyspersyjnym sposobem pisania u Hrabala, które spróbujemy ześrodkować za pomocą "domu” Kundery. Odwołamy się do wywłaszczenia, jako do instrumentu narracji: tematyka domu u Kundery stanie się bowiem najpierw antyiluzyjnym komentarzem sposobu pisania Hrabala, by następnie mogła być obserwowana przez pryzmat jego écriture, rozproszonego, ironicznego i sugestywnie nieczytelnego.

\section{KIM JEST WRAŻLIWY AUTOR? FRAGMENTARYCZNOŚĆ WOBEC INTEGRALNOŚCI, ÉCRITURE SKRYTE WOBEC SYSTEMATYCZNIE WYJAŚNIANEGO}

Mając na względzie jasność argumentacji i czytelność stanowiska interpretacji, ustalmy na wstępie, że kontrastowość obu autorów będzie rozumiana odwrotnie niż się ją zwykle pojmuje. Ostrzejszy kontur nada temu stanowisku stwierdzenie, że z pewnych rysów twórczości Kundery możemy wyczytać jej liryzm, sentymentalizm, uczuciowość. Mimo że narrator ocenia ją niekiedy negatywnie (za przykład niech posłuży uzależnienie Tomasza od uczuciowej wyobraźni Teresy w powieści Nieznośna lekkość bytu), to jednak pozostaje ona jedną z głównych osi powieści. Dlatego też możemy Milana Kunderę w pewnym sensie uważać za autora prozy sentymentalnej, chociaż sentyment lub w innym miejscu nostalgia może być ironizowana, czy nawet od samego początku pojmowana ironicznie.

Bohumil Hrabal odwrotnie - bywa uważany za pisarza emocjonalnego, zdradzającego serdeczną przychylność do ludzi żyjących na społecznych peryferiach. U Hrabala moglibyśmy mówić o jego zżywaniu się ze światem, który go otacza (Huta Poldi w Kladnie, skup makulatury, lasy w okolicy Kerska, Połabie itd.), Milan 
Kundera tymczasem odznaczałby się pewnym ironiczny dystansem. Nie można, co prawda, zapomnieć o, z jednej strony, kunderowskiej ironii, a z drugiej o sentymentalności Hrabala, dzięki której potrafi zidentyfikować się z losami ludzi zagubionych, jednak na przekór temu zamierzam w przypadku obu autorów zmienić akcenty.

Zamiast mówić o Kunderowskiej ironii będę wskazywać na to, co jest jej obiektem. W ten sposób dotrzemy właśnie do sentymentu i nostalgii, które okażą się pewnie właściwym fundamentem prozy Kundery, co (w jakiejś próbnej perspektywie genealogicznej) może mieć swój zalążek już w Kunderowskiej liryce. Tymczasem wrastanie, zżywanie się i współodczuwanie Hrabala (jego sentymentalność) spróbuję interpretować, jako alibi dla écriture, jako fałszywy ślad, który nas może oddalić od właściwego komunikatu literackiego (i jednocześnie od narracyjnej strategii Hrabala). Jeżeli owo przestawienie dość powszechnego rozumienia obu autorów (Kundera jako ironista, Hrabal jako sentymentalista) miałbym wyrazić jednym zdaniem, Hrabal wystąpiłby w nim jako pisarz ironiczny i cyniczny (chociaż przedstawia tę pozycję bojaźliwie przerażony), Milan Kundera zaś jako sentymentalny autor przejrzyście skonstruowanej prozy.

W owych ekstrapolacjach możemy pójść jeszcze dalej, stwierdzając na przykład, że to właśnie swoistość pisania Kundery w swojej otwartości i przejrzystości nic nie ukrywa (nie ma nic do ukrycia?), w odróżnieniu od na pozór sentymentalnej prozy Bohumila Hrabala, która przeciwnie - jeśli przyjrzymy się jej jako literackiemu écriture, a nie jako pewnemu typu świadectwu - zacznie się prezentować jako ciemna i niedostępna, nie ujawniająca swojego komunikatu, ale raczej go ukrywająca (jakby miała coś do ukrycia). Hrabal w dodatku swoją pokrętność dość lapidarnie komentuje, mówiąc o zabawie z czytelnikiem, jak to obawiał się, że czytelnik dobierze mu się do skóry, odkryje jego autorskie tricki.

Hrabalowski gest jest systematycznie lamany, narrator zaś nie ma zwyczaju zwracania uwagi na te meandry. Możemy również w przypadku Hrabala mówić o implicytnej czy przemilczanej literaturze. Kontrast przejrzystej i ciemnej swoistości pisania wypadnie poprzeć praktyką interpretacji. W przypadku Hrabala nie znajdziemy monografii obejmującej całość jego twórczości, tymczasem już w relatywnie wczesnej monografii Kunderowskiej Květoslav Chvatík nie waha się mówić o „świecie powieści Milana Kundery” Jest więc tak, jakby jednolite, całościowe spojrzenie na twórczość Hrabala wydawało się niemożliwe.

\section{AUTOR, KTÓRY NIE STAWIA NA SWOIM - CZYTELNY ŚLAD TEMATYKI DOMU}

Dlatego też pozwolę sobie mówić o określonej fragmentaryczności écriture Hrabala. Nie wynika to tylko z niemożliwości jego całościowego oglądu, lecz również, jak możemy wywnioskować z komentarzy edytorskich i ze stosunkowo zna- 
nej i powszechnej wariantywności jego dzieła, z tego, że nie ma ono definitywnej postaci tekstowej. Tu przypomnijmy choćby niechęć Hrabala do współpracy przy zbiorowym wydaniu jego dzieł. Prawdopodobna reakcja pisarza wobec wydawniczych nacisków na autoryzację niektórych wersji mogłaby zdaniem jego edytorki Jiřiny Zumrovej brzmieć skąpo (a w pewnym sensie też enigmatycznie): Co jsem vydal, to jsem vydal (pol. Wydałem, co wydałem)4 ${ }^{4}$ W tak lakoniczny sposób Hrabal rozprawia się z kwestią woli autorskiej. Zabiegi autoryzacyjne, jakie przy wydaniach swoich książek podejmuje Kundera, stają tu w ostrym kontraście, przypomnijmy definitywne wydanie twórczości Kundery z 2011 r. w prestiżowej serii La Bibliothèque de la Pléiade w paryskiej oficynie Gallimard.

Prócz fragmentaryczności pisarstwu Hrabala, jak się wydaje, brak również uchwytnych peryferii (co znowu kontrastuje z praktyką wydawniczą Milana Kundery). Jakby sprawę autoryzacji pozostawiał Hrabal w gestii czytelnika czy interpretatora $^{5}$, nie dziwi, że Jiř́ Pelán końcową cezurę dzieła Bohumila Hrabala widzi w Trylogii ${ }^{6}$. To, co pojawia się po niej, już według niego nie ma wartości literackich (z tego powodu krytyk jest obiektem krytyki hrabalologów) - zarazem stanowisko Pelána wynika przecież z charakteru Hrabalowskiego pisania, gdzie dopiero czytelnik (interpretator) gwarantuje sens.

Czy jednak tego typu kwestie, związane z ostatecznym kształtem dzieła, z jego charakterem, nie oddalają nas od tematyki domu? Myślę, że wprost przeciwnie, chodzi tu o istotną wskazówkę dotyczącą tej tematyki, która, jak się okazuje, jest (u obu autorów) związana ze znaczeniowym dookreśleniem, czytelnością, stabilnością semantyki itp. Jeśli kształt dzieła będzie się utrwalać, znaczenia ustalać (taką funkcję mogą też spełniać wprowadzające teksty Ricarda w ostatecznym wydaniu twórczości Kundery), wpłynie to pozytywnie na realizację tematyki domu (i to na przekór ironicznym inwektywom itp.), fragmentaryczność zaś i nieprzenikniony charakter pisania wywołuje rozdrobnienie i problematyzację tematyki domu, jako miejsca dającego się pozytywnie określić w przestrzeni. Zapewne nie przypadkiem dla edycji dwóch esejów, w których zajmuje się problemem autorskiego testamentu, Kundera wybiera ostentacyjny tytuł: Nechovejte se tu jako doma, př́teli (Nie zachowuj się tu jak w domu, przyjacielu) ${ }^{7}$. To ostrzeżenie jasno ukazuje, jak bardzo kwestia domu będzie się łączyć z problemem woli autora, który może także skreślać i przepisywać, to, co już kiedyś napisał. Odnośnie eseistyki Kundery i jego strategii edytorskiej możemy obserwować, jak bardzo tematyka domu. jako parafowanego przez autora horyzontu sensu. łączy się z definitywno-

${ }^{4}$ J. Zumrová, Edični poznámky, w: B. Hrabal, Pábení: povídky z let 1957-1964. Sebrané spisy Bohumila Hrabala. Tom 4. Praha 1993, s. 404.

${ }^{5}$ J. Češka, op. cit.

${ }^{6}$ J. Pelán, Bohumil Hrabal. Pokus o portrét. Praha 2002, s. 67-68. Hrabalowską trylogię stanowią nowele Svatby v domě, Vita nuova, Proluky.

${ }_{7}^{7}$ M. Kundera, Nechovejte se tu jako doma, príteli. Brno 2006. 
ścią dzieła literackiego. Zapewne dlatego Sylvie Richterová mówi o języku literatury jako o drugim domu ${ }^{8}$.

W strategii edytorskiej Kundery, w jego chęci nadawania swym dziełom ostatecznego kształtu, zarejestrowaliśmy znak dla tematyki domu istotny, który określiliśmy jako znaczeniową stabilność. Pozostawmy jednak to dość rozległe ujęcie, w którym tematyzowaliśmy krańcowo różny stosunek autorów do ich dzieł, zapewne odbijający się na charakterze ich pisarstwa (raczej jednak nie można rozstrzygnąć, czy pierwotny jest tu stosunek autorów do pisania, czy też właściwy charakter pisania). Zajmijmy się teraz rozważeniem konstrukcji écriture, wychodząc od kontrastu znaczeniowej dookreśloności wobec jej braku. Tym szlakiem powinniśmy dotrzeć do bardziej szczegółowego opisu swoistości pisania, a więc w końcu także do właściwej interpretacji tematyki domu.

\section{POSZUKIWANIE TEMATYKI DOMU NA POZIOMIE ÉCRITURE}

Nie jest pewne, czy będzie można odróżnić specyfikę pisania obu autorów za pomocą odpowiedniego czysto narratologicznego kryterium. Jednak zmierzając najpierw w tym kierunku, wyznaczymy jako kryterium typologiczne wewnętrzną fokalizację (oświetlenie wewnętrznego świata postaci), która staje się głównym środkiem narracyjnym, na którym Kundera buduje dynamikę swojego powieściowego świata. Znajdziemy, co prawda, ten środek formalny również w prozie Bohumila Hrabala (Zbyt głośna samotność, Skarby świata całego, Obstugiwałem angielskiego króla, Trylogii), jednakże u Hrabala środek ten odgrywa inną rolę.

W czym tkwi różnica, skoro w czysto formalnym kryterium wewnętrznej fokalizacji jej nie znajdziemy? Może uda się ją odkryć w ustabilizowaniu Kunderowskiego świata powieściowego przez suwerennego narratora, który może przeniknąć samowolne monologi postaci (tego środka Kundera często używał), choćby po to, by je komentować, wskazywać niewłaściwą stylizację, nierozważne zaślepienie postaci itp. Wewnętrzny świat postaci jawi się, jak gdyby był (u Kundery) pod trwałą kuratelą narratora, który czasem nie wzbrania się, by ustawić rzeczy na właściwym miejscu

\section{KRYTERIUM TYPOLOGICZNE - KUNDERY SPECYFICZNIE BUDOWANA WEWNĘTRZNA FOKALIZACJA}

Jeśli się dobrze orientuję, podobnego głosu najwyższego narratora brak w prozie Hrabala. Jak gdyby wewnętrznych monologów postaci, ich myśli czy ich rozwle-

8 S. Richterová, Místo domova. Brno 2004. 
kłych wypowiedzi nie można było zastąpić żadnym innym głosem. I choć Hrabalowscy narratorzy (m.in. matka, Hant'a) dopominają się sedna, nigdy żadnej głębi nie osiągną, bowiem ich spojrzenie i komentarz jest zawsze zawodny, wydaje się, że tylko wymacuje powierzchnię i nie jest w stanie zobaczyć czegoś więcej, że nie może zobaczyć odwrotnej strony. Tak jakby narratorzy Hrabala znajdowali się w sytuacji podobnie krytycznej jak nasze sądy, sytuacyjnie uwarunkowane. Jakby ślepe opowiadanie Hrabalowskiego świata zostało pozbawione tej ugody, którą mógłby wnieść głos nadrzędnego narratora. Cóż z tego, że byłby to głos iluzoryczny.

Jednocześnie zaś owo powierzchowne spojrzenie Hrabala, przeskakujące z miejsca na miejsce, jakby rzeczywiście mogło dojrzeć jakąś głębię, paradoksalnie ewokuje przekroczenie literatury, sugeruje tajemnicę daleko bardziej niż dobrze oświetlone i narratorsko zhierarchizowane pisanie z powieści Kundery. Również i tu poruszamy się wokół kluczowej kwestii domu, która łączy się ze stylem opowiadania - w świecie rozwarstwionym i przejrzystym, za który ręczy suwerenny narrator, łatwo wytyczymy granicę między domem a tym, co obce. U Hrabala odwrotnie, granica ta jest wyznaczona negatywnie, bowiem dom jest $u$ niego niemiejscem. Atopia okazuje się istotnym rysem jego pojmowania domu.

Jako pierwszy znak odróżniający écriture obu autorów jawi się Kunderowska specyficzne tworzona wewnętrzna fokalizacja, przez nią $\mathrm{w}$ razie potrzeby przenika swoim komentarzem narrator, znaczeniowo ją stabilizując. Ta właśnie elementarna struktura planuje pewną organizację: narrator podporządkowuje sobie postać (może ją przejrzeć i przeoczyć). Tego elementu struktury u Hrabala nie znajdziemy. Bohaterowie, nawet kiedy opowiadają, nie zostaną nigdy przez żadną nadrzędną instancję narracji poskromieni (albo używając Gombrowiczowskiego wyrażenia, upupieni). Od owej elementarnej dystynkcji struktur przejdźmy teraz do właściwego charakteru wypowiedzi.

\section{PRZYCZYNA OMYŁEK POSTACI: CZYTELNOŚĆ I OBLICZALNOŚĆ ZNACZENIA (KUNDERA) WOBEC ZASADNICZEJ NIECZYTELNOŚCI SYTUACJI (HRABAL)}

Tu zacznie się, jak sądzę, ukazywać specyfika zrymowania powieściowego świata Kundery, narratorski element struktury bowiem zdaje się rymować (literacko współbrzmieć) z wypowiedzią postaci, która jakoby nie mogła się wydostać $\mathrm{z}$ binarnie skomponowanego świata. W prozie Milana Kundery wypowiedź postaci systematycznie segmentuje świat aż do pewnego elementarnego poziomu. Zapewne znaleźlibyśmy również inne przypadki niż alternatywy (choć nie wiadomo, czy w końcu i tych przypadków nie moglibyśmy wpisać w układ binarny), jednak 
również w tych przypadkach istotne będzie to, że można każdą sytuację rozłożyć na ograniczoną liczbę znaczeń, które wyczerpują jej potencjał semantyczny (jako czytelnicy nie rejestrujemy żadnej reszty).

W powieściach Kundery sytuacje mogą mieć więcej znaczeń, nie będą jednak nieczytelne. Błąd wynika z tego, że mylnie określamy ich znaczenie, nie stąd, że nie potrafilibyśmy sobie z nimi poradzić. Stosunek Tomasza do Teresy (Nieznośna lekkość bytu) cechuje prosta alternatywa: histeria lub miłość. Jego niezdecydowanie wynika z czytelności, on tylko nie potrafi wybrać właściwego rozwiązania alternatywy. Sytuację zanalizujemy wyczerpująco, błąd powstanie wówczas, gdy wybierzemy niewłaściwą interpretację.

Takiego ujęcia u Hrabala, jak sądzę, nie znajdziemy. Pomimo tego, że postaci również u niego są czytelnikami sytuacji i własnego życia, ich wahanie i niepewność nie wynika z niemożności określenia tego, która z naszkicowanych możliwości jest właściwa, wynika natomiast stąd, że w ogóle nie mogą dotrzeć do tego, co właściwie pewne życiowe perypetie i sytuacje oznaczały (sytuacje wytrwale opierają się lekturze). Zapewne tu można się doszukiwać genezy nieustannie wszczynanych przez Hrabala iluzyjnych napaści. Lektura u Hrabala wciąż nie dobiega końca, w przeciwieństwie do świata Kundery, który jest wprawdzie odczytany, ale zupełnie nieokreślony.

W powieściowym świecie Kundery każda sytuacja miała być jakby opatrzona znaczeniem albo jakąś klasą znaczeń. Jeśli narrator oferuje nam gwarancję sensu, jeśli potrafi obliczyć znaczenie jakieś sytuacji, to pisanie $\mathrm{w}$ ten sposób konstruowane będzie, jak już to zostało kilkakrotnie powiedziane, przejrzyste i uporządkowane. Przyjrzyjmy się jeszcze ostatniemu znakowi czytelności rękopisu Kundery, wspomnianej już binarności. Figura ta jest u Kundery podstawowym elementem strukturującym, z innego punktu widzenia moglibyśmy o niej mówić jako o strategii dookreślenia. Hrabalowska symbolika jest w porównaniu z nią rozproszona.

\section{KLĄTWA BINARNOŚCI: LOS I OSĄD}

Binarność możemy najprościej zilustrować tematyką losu, u Kundery centralną, u Hrabala zaś nieodgrywającą istotnej roli. Dodatkowo los bardzo dobrze rymuje się ze znaczeniową dookreślonością, jest bowiem ściśle związany z czytelnością. Kto się przegląda $\mathrm{w}$ zwierciadle losu, ten stoi $\mathrm{u}$ progu alternatywy: akceptacja/wzgarda, wybraniec/potępieniec itp. Postaci Kundery coś jakby korciło do oglądania się na jednym z obrazów malowanych przez los, który staje się motywem ich ruchu. Na ich drodze nie zjawia się żadna przeszkoda, żaden rywal, przeciwnik, postaci jednak dążą wciąż do tego, by czytać w księdze losu i w ten sposób odkrywać, kim właściwie są i co mogą zrobić dla polepszenia swojego wi- 
zerunku przez los nakreślonego (na przykład Mirek z Księgi śmiechu i zapomnienia). Najlepszym zapewne przykładem rozmowy postaci z losem będzie główny bohater Walca pożegnalnego - intelektualista Jakub, który zdecydował się na emigrację. Każde podjęte przez Jakuba działanie zyskuje sens dopiero w krzywym zwierciadle losu. Jest ono skomponowane binarnie - należy je pojmować jako przedmiot samowoli albo odwrotnie - jako jej podmiot. Czy zatem Jakub jest prześladowanym, czy tym, który prześladuje, bezsilną ofiarą albo odwrotnie - zabójcą?

Tematyka emigracji w Walcu pożegnalnym będzie kolejnym przykładem binarności - Jakub pojmuje emigrację jako ucieczkę z kraju niewoli do kraju wolności. Kiedy sklasyfikuje Růženę jako synekdochę kraju niewoli („służka katów”), bawi się jej życiem i śmiercią. W ten sposób w Walcu pożegnalnym (i nie tylko tam) wszystko rozpada się na alternatywy: przykładowo, główna kwestia, jaką jest ojcostwo, zostanie spolaryzowana przez tematykę ekwiwalentną, centralnym problemem będzie pogodzenie ze światem i z życiem, albo przeciwnie - niezgoda.

W Walcu pożegnalnym nie można powiedzieć niczego, co by nie miało komplementarnej antytezy. Jednocześnie możemy zaobserwować, w jakim stopniu ta manicheistyczna osnowa będzie związana $\mathrm{z}$ konkretnym miejscem albo też z określonym horyzontem symbolicznym. Wyznacznikiem centrum i peryferii będzie właśnie postać, jako jądro opowieści, centrum snucia i komponowania literackich iluzji. W tym ujęciu dom nie zwiąże się ostatecznie z określonym miejscem, raczej z pewnym symbolicznym horyzontem, co można bardzo dobrze uzasadnić pokazując, jak dla Kundery drugim domem staje się jego dzieło (por. wspomniany już esej Nie zachowuj się tu jak w domu, przyjacielu).

\section{ZALĄŻEK TEMATYKI DOMU: INNE ROZUMIENIE LIRYZMU}

Dokładniejsze opracowanie tematyki domu wymagałoby zwiększenia zakresu obserwacji, dlatego też pozwolę sobie wyznaczyć tylko możliwe kierunki refleksji. Czyż nie można odnaleźć zarodka tematyki domu u Kundery w jego liryce, podobnie jak $\mathrm{w}$ jego rewolucyjnym projekcie języka poetyckiego (mocno zainspirowanym przez poezję Nezvala9 ${ }^{9}$, który miał zwrócić człowiekowi świat, jaki stał dla niego obcy? Poezja może ten utracony świat uczłowieczyć, udomowić: także tu oddziałuje binarną osnową - to, co obce i wrogie, zostanie udomowione.

Chociaż w twórczości obu autorów liryka spełnia funkcję inauguracyjną, mamy do czynienia $\mathrm{z}$ dwoma różnymi typami liryki. Możemy więc $\mathrm{w}$ odmienności liryzmu Kundery i Hrabala upatrywać różnych prefiguracji ich twórczości, a także zapowiedzi różnic écriture. Podobnie jak w przypadku późniejszej prozy możemy

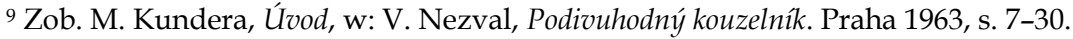


bowiem mówić o binarności wierszy Kundery, wiersze te mają, w dodatku, wyrazistą składnię, co zapewne wynika z ich epickości. W przeciwieństwie do nich składnia poezji Hrabala jest wyraźnie osłabiona, obrazy poetyckie komponowane są paralelnie, drobnych motywów nie sposób zlokalizować w czasie (są więc $\mathrm{w}$ pewnym sensie nieumiejscowione).

Czy już we wczesnej poetyckiej twórczości Kundery nie rodzi się przypadkiem horyzont takich tematów jak dom, powrót, potępienie, centralna figura myślenia binarnego?

„A když se vracel do své domoviny,/ zalil ho náhlý pocit viny.// A když pak rodné střechy uviděl,/ nesměle, váhavě jen šel.// Ale v jeho čtvrti okna se otvírala všade/ a ti, jež dříve míjel s ostychem, volali na něj: Vítej, kamaráde!" (Kiedy powracał do swej krainy,/ zlało go nagłe poczucie winy.// Gdy ujrzał kształt ojczystych strzech,/ zawahał się, nieśmiało szedł.// Lecz w jego osiedlu okna się nań otwierały,/ a wielu z tych, których ze wstydem mijał, wołało: Witaj, przyjacielu!)

(Od obzoru jednoho k obzoru všech, Člověk zahrada širá, - Od horyzontu jednego do horyzontu wszystkich, Człowiek ogród rozległy).

W tej małej próbce możemy zmieścić esencję tematyki domu - powrót, dozór, strach przed brakiem akceptacji - wahanie, zażenowanie, radosne powitanie. Może ta mikrosekwencja jest właśnie podstawową intrygą powieściowego świata Kundery? Kwestia akceptacji jest aktualna jeszcze w powieści Tożsamość, gdzie Jean-Marc rozstaje się ze swoim przyjacielem, ponieważ ten go nie wziął w obronę.

Jak gdyby wszystkie postaci traumatyzowała myśl o tym, w jaki sposób ocenią ich inni. Czy wyjściowej sytuacji w powieści Żart nie możemy rozumieć analogicznie do tematu powrotu w cytowanym wyżej wierszu? W Żarcie główny bohater Ludvík Jahn może po piętnastu latach znaleźć się w domu jedynie o tyle, o ile zamierza wyrzec się zemsty na Pavle Zemánku: liryczność domu pozostaje, przybywa za to cyniczne i ironiczne uzasadnienie opowieści. Intryga planowana przez Ludvíka dostarcza mu alibi przed możliwym zarzutem sentymentalności. Czy nie można więc już w Żarcie usłyszeć tego podskórnego tonu opowiadania, w którym pobrzmiewa sentyment do ojczystej ziemi? Przykładem niech będzie końcowa scena muzykowania $\mathrm{w}$ kapeli $\mathrm{z}$ cymbałami, kiedy to odtajały emocje głównego bohatera Ludvíka Jahna.

Ów powieściowy powrót Kundery do fundowanej na liryzmie tematyki domu zapewne nie jest wyjątkiem: przypomnijmy choćby wytęskniony powrót Teresy (z Nieznośnej lekkości bytu) do domu rodzinnego. Takie powroty związane są z wyobrażeniami idylli i szczęścia. Idylla, co prawda, może być w różny sposób karykaturowana, pozostaje jednak określona jako biegun pozytywny, jako niezawodnie lokalizowalne miejsce. Także wtedy, gdy $\mathrm{z}$ uwzględnieniem przemiany konfiguracji symboliki obce przemieni się $\mathrm{w}$ dom i odwrotnie, jak w przypadku samego Kundery, naturalizowanego autora francuskiego. Jego identyfikacja 
z dziełem, kulturą francuską, kontrolowanie i domaganie się prawa autoryzowania filmów czy adaptacji teatralnych, świadczy o oczywistym zaangażowaniu, w którym z pewnością nie ma śladu cynizmu czy ironii. Dom nie jest więc u Kundery związany $\mathrm{z}$ jakimś miejscem, jest symbolicznie performowany $\mathrm{w}$ binarnej osnowie dom - to, co obce, w czym można również upatrywać lirycznych fundamentów domu.

Patrząc na stosunek Hrabala do jego utworów, ich zbiorowego wydania, do autoryzacji życiorysu ${ }^{10}$, filmowych opracowań jego dzieł (spór o prawa do filmowej adaptacji noweli Obstugiwatem angielskiego króla), albo wreszcie na jego stosunek do narodu, nie możemy też mówić o niezaangażowaniu, ironii i cynizmie. Jednak, czy nie odpowiedziałby nam na tego typu pytania: a czy to nie wszystko jedno?

\section{DOM JAKO ŚRODEK GRAWITACJI CZY JAKO MIEJSCE ODŚRODKOWE?}

Na zakończenie, po tym, jak écriture Hrabala określaliśmy poprzez negatywną formułę, wymieniając najczęściej to, czym odróżnia się jego pisanie od pisania Kundery, spójrzmy na właściwe Hrabalowi ujęcie domu, uwzględniając nie tylko formę komunikatu, ale też tematykę, która u Hrabala łączy się w oczywisty sposób $\mathrm{z}$ domem.

Dopiero teraz, jak mniemam, Kundera ujawnia się w całej pełni jako ideolog domu. Przecież jego postaci drżą z obawy przed brakiem akceptacji, a jeżeli ją znajdują w ojczyźnie lub w ziemi niewoli, decydują się szukać gdzie indziej. Wydaje się więc, jakby w dziele Kundery niemal każdy dowolny ślad był symbolicznie śladem domu. Życie Taminy (Księga śmiechu i zapomnienia) koncentruje się na pisaniu (listy i dzienniki). Na emigracji żyje jakby pozbawiona życia nie dlatego, że mogłaby zostać odseparowana od bliskich w niedostępnym obcym kraju (z powodu żelaznej kurtyny), odwrotnie, tę odległość odczuwa zapewne jako wyzwolenie (z kręgu despotycznych rodzinnych więzi), najpewniej dlatego, że została pozbawiona symbolicznego horyzontu miłości, listów od zmarłego męża i intymnych dzienników. Jedyny sens jej emigracyjnego życia to usiłowanie odzyskania tych pamiątek. Dom i bliskość rozumiane dosłownie czy przenośnie są dla postaci pozytywnym biegunem ich ruchu, który wydaje się być esencją ich tożsamości. Jest tak również w przypadku Sabiny (Nieznośna lekkość bytu), zdefiniowanej jako przemieszczająca się negacja - jednak pomimo tego, paląca nostalgia dopadnie ją w końcu daleko od domu, w USA.

10 Autoryzowana przez Hrabala autobiograficzna powieść Moniki Zgustovej wywołała u strażników Hrabalowskiego dziedzictwa niezadowolenie i polemikę. Zob. M. Zgustová, V rajské zahradě trpkých plodi̊. O životě a díle Bohumila Hrabala. Praha 2004. 
Wydaje się więc, że gdy w świecie powieści Kundery (i chyba nie tylko tam) dom jest pozytywnym biegunem, który postaci chcą osiągnąć, u Hrabala jest odwrotnie. Dom jest miejscem jak gdyby wciąż nie tym, do którego docierają Hrabalowscy bohaterowie. Jakby nie był celem wędrówki, lecz odwrotnie miejscem, z którego się ucieka. Dom jest miejscem, gdzie dochodzi do zabójstwa (Miasteczko, gdzie się zatrzymat czas), gdzie wszyscy bliscy wciąż na siebie wchodzą (w willi w nymburskim Połabiu - Skarby świata catego), dom jest ścieśnioną przestrzenią, zasznurowaną sensem, nie znamionuje jej nic prócz śmierci (Pan Karka - Święto przebiśniegu).

Jeżeli u Kundery dom, także w jego symbolicznej pozycji był polem grawitacyjnym, do którego wszyscy podążają z ochotą, u Hrabala jest całkiem odwrotnie, pole grawitacyjne zostało wprawdzie zachowane, ale jest to raczej czarna dziura, która zamierza połknąć wszystkich. Jak gdyby postaci Kundery wolały przyspieszyć, żeby jak najszybciej (choć nie bez wahań) znaleźć się w domu, u Hrabala zaś pragnęły być odeń jak najdalej. Hrabal poszukuje pozytywnego znaczenia domu tylko w jego atopiczności - jak już zostało powiedziane na wstępie, dom to radykalne i zasadnicze nie-miejsce. U Hrabala owo nieumieszczenie zostało wyrażone lapidarnie w Święcie przebiśniegu: Jak by tady bylo krásně, kdybych tady nebyl já (Jakby tu było pięknie, gdyby mnie tu nie było) ${ }^{11}$. Dom jako biegun dodatni wydaje się tworzyć w powieściowym świecie Kundery swój własny środek (właśnie dlatego jest to świat skoncentrowany, ześrodkowany), w odróżnieniu od systematycznie rozpraszanego świata Hrabalowskiej prozy.

Jeżeli świat Kundery można opisać metaforą grawitacji (motywy niby planety wędrują po wyznaczonych torach), to do opisania Hrabalowskiego świata bardziej odpowiednia będzie metafora czarnej dziury, metafora rozszerzania, wielkiego wybuchu. Jakby odśrodkowości pisania Hrabala nie dało się zatrzymać. Specyfika jego pisania nie ma żadnych peryferii ani żadnego finalnego stadium, z trudem przypomina się zaledwie jego początek. Tak jakby nie mogło go zatrzymać nic prócz nagłej śmierci autora. Jakby ekspandujące écriture nawet nie pozwalało jego autorowi umrzeć. Tymczasem Kundera swój dośrodkowy, koncentryczny świat zaparafuje za życia, zapewne dlatego, że jego pisanie nie ma charakteru odśrodkowego. 


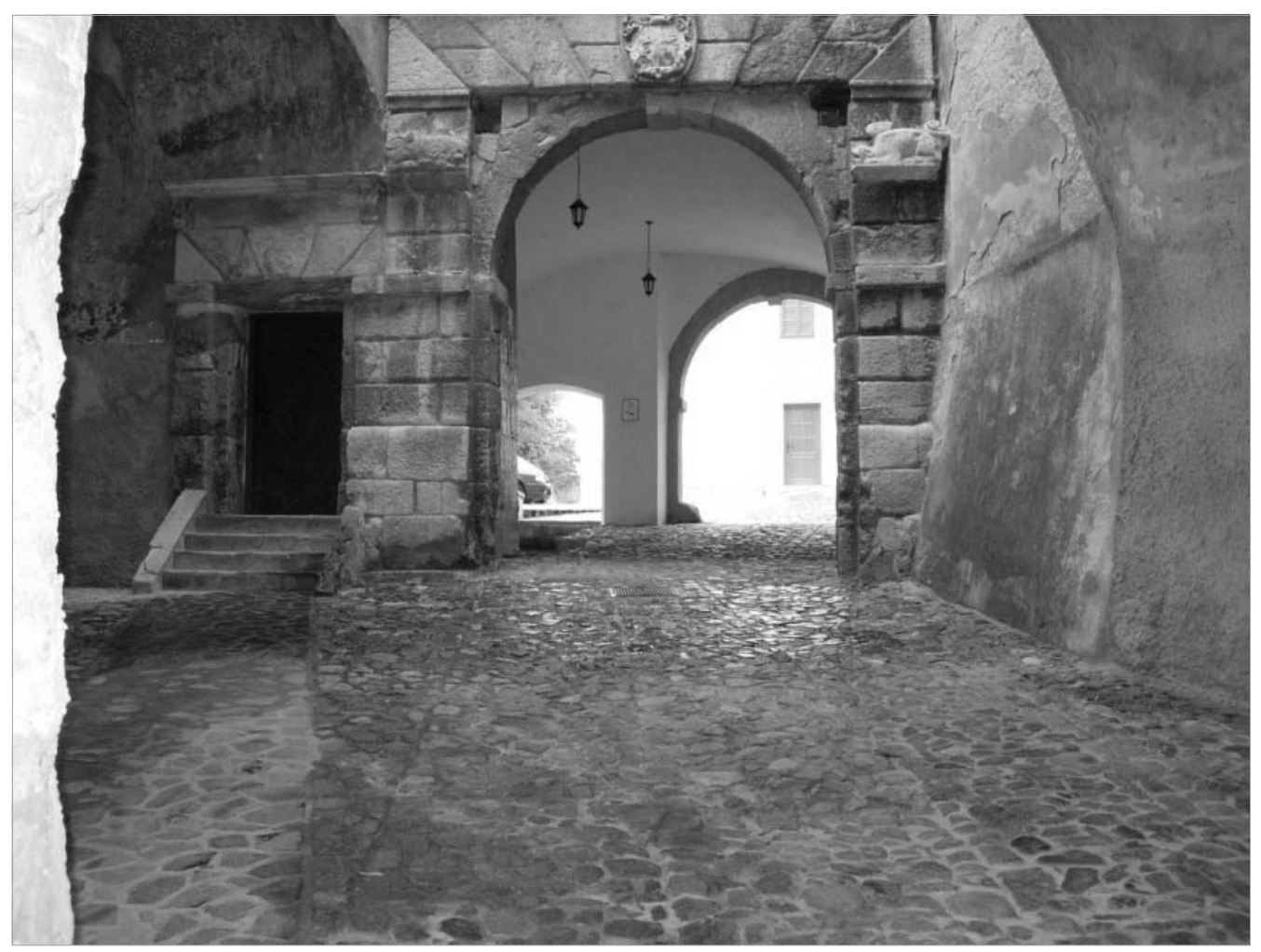

